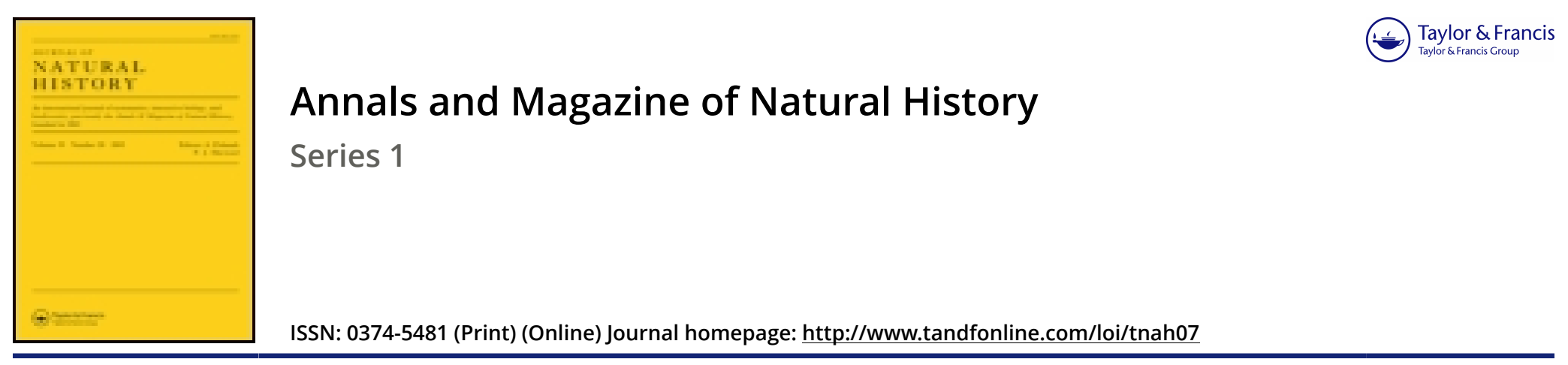

\title{
XIII.-Observations on the Structure of the Pollen Granule, considered principally in reference to its eligibility as a means of Classification
}

\section{Arthur Hill Hassall M.R.C.S.L.}

To cite this article: Arthur Hill Hassall M.R.C.S.L. (1841) XIII._Observations on the Structure of the Pollen Granule, considered principally in reference to its eligibility as a means of Classification, Annals and Magazine of Natural History, 8:49, 92-108, DOI: 10.1080/03745484109442737

To link to this article: http://dx.doi.org/10.1080/03745484109442737

曲 Published online: 04 Dec 2009.

Submit your article to this journal $₫$

Џll Article views: 1

View related articles $\sqsubset$

Citing articles: 1 View citing articles $\asymp$ 
92 Mr. IIassall on the Structure of the Pollen Granule.

lati, horizontalcs, interstitia bilinearia. Fructus ifnoti, color coccincus; cxsiccatus rigidus, charta minimì adharens.

Hab. ad Port Natal.

272. Marlensia, gen. nov. Frons plann, arcolata, arenia, margine fenestrata; fructus duplex; sphrcrospernnia longitudinaliter in reticulo simplici seric disposita; crusula spharice, reticulo aflixx, sporidia subglobosa forentes.

$M$. clegans, $\mathrm{Hg}$. Fronde tenuissima, lobata, segmentis cuncato-rotundatis.

Frons basi affixa, scmi usque pollicaris, tenerrima, tenax, cellulis angulatis arcolnta, margine demum fructifiennte, clatlirato-fenestrnta. Color nuane roscus fugnx. Chartx arctic adlarens.

l'ort Natal ad lapides.

In memoriam amicissini Georgii de Martens, nuctoris Flora Wirtembergicx, algarum inaris Mediterranei scrutatoris indefessi. -llering.

197. Ncmalion Natalense, $\mathrm{Hg}$. Fronde filiformi, ramosa, ramis clongatis, villosis, villis articulatis.

Color olivaceus, chartic arcti nilharens. Hab. nd P'ort Natal Point, Afr. meridionalis.

Fucus minimus, $\mathrm{Hg}$. Fronde plana ecostata, lincari, dichotoma, integerrima.

V'ix pollicaris, fronde scmilinearn lata, spiraliter tortin.

Port Nutal.

XIII.-Observations on the Structurc of the Pollen Granule, considcred principally in reference to its cligibility as a means of Classification. By MnTuUn Hni. Ilassani, M.R.C.S.L., Corresponding Member of the Dublin Natural Ilistory Socicty.

IT has often been a mntter of surprise to me, that no one of the numerous and gifted volarics of those bright and beantiful crentions, flowers, which are scattered with so profuse a hamd over moor and mountain, on hill and through dale, should have fully investigatecl the structure of the pollen grnnule in the various tribes of plants, with a view to ascertain whether it could be rendered arailable for the purpose of classification.

Much has indeed been written upon its general anatomy; but the characters of the granules, as they occur in cach genus of plants, appear to have been scarcely at all considered in this country, and almost the only figures which we possess of individual pollen grains are contained in Lindley's 'Introduction to Botany,' and were derived from a work of Purkinje on the subject*.

- These figures are but little morc than mere outlines, and cren in this single particular are generally very far from being correct. 
On the Continent entire works have been published upon the pollen, accompanied by numerous figures: I nllude particularly to Purkinje's work, ' De Cellulis Antherarum fibrosis,' \&.c.; to that by Fritzsche; and to a menoir by Mohl in the 'Annales des Scienecs Naturelles,' all of which have appeared within, I beliere, the last ten years.

With the opinions contained in these works I am only acquainted in so far ns they are given us by Lindley, as I wished, before consulting them, to form a scparate nnd independent opinion, so that all I shall ndvance in this paper is to be regarded only as the result of my orrn investigations, nud rests upon my own responsibility. It is my intention to publish, from time to time, a series of papers upon the subject of the Jollen, in some of which I shall give the opinions of the authors to whom I have referrel more at length; thus my not doing so at present will be of but little consequence.

Although I do not anticipate that the results of this inquiry will be very considerable in a practical point of view, l yet fecl that I ought not to be deteried from the pursuit because I am not at once able to perceive any grent utility attached to it ; the subject is one of much interest in itsclt, and mny ultimatcly lend to more than is at present looked for.

I could have wished that an investigation of such nicety and extent had fallen to the lot of some individual of greater capability and experience in microscopical research; but as this is merely an cssay, and as I shall ndrance nothing but what I hnve fully made out, I trust that the inquiry will not suffer by renson of my comprarative inefficiency for the tisk I have undertaken.

Conceiving then that the want of an accurate knowledge of the form and structure of the pollen grain in the different genera of plants constituted a desideratum in botanical scicnce, I commenced the investigations the results of which I am about to detnil carly in the spring of last year, continued them throughout the grenter part of the summer, and the small amount of time which I have this senson been able to spare from professiunal pursuits has been cmployed in correcting and confirming the conclusions previously arrived at.

I shall divide my subject into three heads. Under the first head, the pollen generally will be spoken of; under the second, the indivilual peculiarities of the pollen granule will be notiecd; and lastly, the pollen will be considered with a vicw to ascertain whether it can be rendered available as a means of classification.

First then, of the pollen generally: 


\subsection{Mr. IIassall on the Structure of the Pollen Gramule.}

The structure, form, and size of the pollen granule varies considerably in different tribes of plants.

There are, however, certain types of structure and of form which occur more frequently thin others. Of these, the cylinclrical and elliptical are by far the most conmon; and rext, in frequency of occurence, aure those granules of either a trinngular or circular form, which are met with in nearly an cqual proportion. A great variety of other forms are to be noticed, which it is the object of this paper especially to describe.

The term cylindrienl is applied to oll those grains which are more or less of an clougated form, are somewhat triangular, and taper towards each extremity, which cxhibit n furrow along thcir upper surfice, and are furnished with thrce pollen tubes; while the word elliptienl is used to designate those granules which agrecing somewhat with the former in their lengthened shape, having also a line upon their surface, yet possess but onc pollen tube.

On the application of any fluid to pollen of an elongated form, of Iess density than the fovilla contained in the cells, $n$ remarkable alteration of sliape talics place with great quickness. Ench grain of pollen, prior to the contact of the liquicl, lies on the object-rlass of the microscope with its long dinmeter placed loorizontally; inmediately on its touching it the position of the long dianeter is changed, it becomes vertical, and the pollen gian, losing in length, dilates and becomes of a triangular or circular form ; and this change of form, which is here produced by the direch application of the water, occurs nlso naturally previous to the enission of the pollen tubes, arising partly from the nlsorption of fluid from the tissuc of the anther, but mainly from the inbibition of the stigmatic secretion. I3ut if a fluid of greater density than that within the cell be appliecl, no such change is seen to occur, a contraction of the pollen grain and an cxuclation of a portion of its contents taking place.

'This altcration of form, in both instances, is very satisfactorily explained by a reference to the principle of culdosmosis and cxosmosis, which is most beautifully cxemplificd in the interesting though minute subjects of the present inquiry, and all the varied phenomena of which are referred by Dutrochet to capillary attruction.

Each pollen grain consists of a turbid fluid called fovilla, containing numerous active molccular particles; and this fluid is cnclosed, nccording to most obscrvers, in at lenst two membrancs, the outer being called cxtine, the inncr intine, and this is of a highly extensible nature. 'The only exception to this, nccording to Mohl, is the pollen of Asclepialaceous 
plants, which has but onc cnvclope ; but Fritzsche has asserted, nccording to Lindley, that these plinnts have both an extine and intine. Fritzsche also states, that in Caulinia frayilis, Zannichelliu peclunculata, Zostera marina, and Naius minor, the pollen bas really nothing but the intine present.

'That there really are two contings to the grent majority of pollen granulcs does not admit of a doubt; while a third membrane, intermediatc between the cxtinc and intinc, has been noticed, first by Mohl and subsequently by Fritzsche, who calls it exintine. Mohl observed it in the pollen of Taxus, Juniperus, Cupressus and Thuja; and Fritzsche finds it not only in these plants, but also in P'inus, Cucurbila P'cpo, and Tigridia Pavonia; while MIr. Giraud* states (in the third rolume of the 'Anmals and Magazine of Natural History,' p. 127) that lie las noticed it in the pollen of Crocus vermus. 'I'o these I may udld the pollen of the different species of Bunksia and Dryandia as possessing a third membrane, as well as the following list of plants, Fuchsia fulgens, F. cylinelrica, F. thymifolia, F. gracilis, and $F$. coccinca, Stachytarpheta mutabilis, 'Tilin americana, Culothammus villosus, Zizyphus Paliurus, and probably also Grevillea linearis, IIukia pedunculata, Eryllhrina laurifolia, Dieliscus ccerulcus, liumaria officinalis, ancl all other species of Fuchsia. It is necessary to observe grent caution in deciding upon the presence of a third membranc, as an appenrance is frequuently olsscrved which might mislead; it arises from the cntrance of water within the sac of the intinc, scparating the fovilla from it, forcing it inwards, and giving it a very defined inargin.

At the commenecment of this inquiry, I was induced to consider that the reticulation olsservable on the pollen of Pancratium, Armeria, Slatice, Passiflora, \&c. constituted the basis of a distinct membrane, and in the figures of these which will follow it is so represented. To this opinion I was led by noticing the raiscd nppearance which it presents, especially round the circumference of the granules, as well as from the circumstance of the cncls of ezch grain of pollen in P'uncralium being destitute of the reticulation; but it is more correct, perhaps, to regard this reticulated appearance as produced by the apposition of the cells of which the extine is formed in these instances.

Fritzsche also speaks of a fourth cont, which is next the extine, nnd which he calls intextine, as belonging to the pollen of Clarkia elegans and other Onagrariac. Of the existence

- Mr. Giraud, in the same communication, mentions having seen small opate particles on the sirface of the pollen givin of l'olitioninm coruleun, which exhibit a peculias mution when the granules are placed in water. 
of this menbrane in Clarkia I have but little doubt, and I belicre that it is also present in those species of Fuchsia which I have mentioncel ns posscssing a third tunic, as there are in the pollen of these preciscly the same appearanecs upon which the opinion of its presence is founded in Clarkia eleguns.

The pollen gramules of Saponavia viscida present, when vicwed throught the medium of oil, a very reniarkable appearance, which I am only nble to cxplain by supposing that it depends upon some peculiar inversion or pittingr of the cxtinc. It conveys the iclea of a membranc of a circular furm, smnller than the extine, being planed within it, nnd pollen tubes to the number of ten escepling through npertures in it and extentingr to the margin of the outer membrane. I referto this alyearance liere in the hope of lirecting the attention of other ulscevers to it, who may perhaps be nble to afford a more particular explannation of its nature.

In the lonit axis of those granules to which the terms cylindrieal and elliptical are here applied, as well as of many others, $n$ line or furrow; as has been already remarked, is noticel, concerning the nature of which various conjectures have becn hazardcel, and none of which afford the true cxplanation of the phinomenon. Malpighi compared granules of pollen of this kinkl to griins of whent, on nne sitle of which at furrow cxists ; but this docs not account for the furrow being visible in crery grain at the same time; Guillemin, attempting to account for the constant presence of the line, says that it exists on both sides of the grain. IIc further supposes this furrow to be a slit intendcel to facilitate the arlmission of water into the interior of the granules, and the emission of their contents; neither is this explanation more satisfactory. Fritzsche states it to be a thin part of the extinc where the sides of the pollen grain are contracted and mect, producing the appearanee of a furrow; while MIr. Giraud regards this line as a mere furrow in the extinc which disnppears on the application of moisture, in which opjinion l'rofessor Grahnm coincilcs*; but neither of these gentlemen ofter nuy cxplnnation cither as to its origin or use.

'The true explanation of the nature of this furrow, about which there are so many opinions, is, that it is a cleficiency in the external inembranc of the pollen grain, intended to facilitate the egress of the pollen tubes, one of which may be distinctly secn to issue from ench; and the fact of its lieing seen at the same moment in every grain of pollen is accounted for by reference to the form of these granules. Those grains

- Sce Mnn, and Mag. of Nat. Hist. alrcady referred to, and l'ruf. Graliain's Third Annual IRepurt, read before the Iotanical Sucicty of Edinburgli, March 1811 . 
of pollen to which the term cylindrical is applicel, are, as has becn already noticed, more or less of a triangular or trilobitte form, and at each angle, or between ench lobe, a furrow exists; so that, as cach granulc, from its shape, must rest upon one or other of its sides, oute angle and one line will necessarily be presented to the eye of the observer. But another explanation is requisite to account for its constant presence in those granules to which the term elliptical is assigned; these, though of an clongated form, like the others, are rounded in their short axes, execpt on une side, which is slightly thattened and indented. In this indenture the single furrow posscssed by these granules is placed; hence it result that cach must rest cither on its fattencel surfice, with the furrow looking downwards, is most frequently happens, in which case it will still be appirent through the hedy of the granule, owing to its transparency; or it will fall on the rounded surface opposite the furrow; which now looks directly upwards. 'l'hus, in whicherer way the grain rests, the furrow will still be apparent. Should it alight upon its side it will not remain in this position, but will roll orer to the convex surface, which constitutes its centre of gravity*.

'The pollen grain of Crinum amabile is flattened and brond on two surfaces, differing in this particular from the pollen of all other Amaryllidacece which I have examined, down each of which a furrow is placed; and from this form also it follows that one line will ever be opposed to view, as the gramules rest upon one of thcir broad surfaces. And again in Citrus uurantium, Ranunculus acris and Rubus fruticosus, the granulcs arc somewhat clongatcd, nnd consist of four lobes, between which the fissures are placed; and as they most generally lie on two of the lobes, the other two, with a fissure between them, will, as a matter of coursc, be turned upwards.

Lastly, many kinds of pollen, as of the Polygala, Crucianella, Laliate, \&e., are furnished with a number of furrows, some of which, in all postures, will be visible. $\Lambda$ careful cxamination of the pollen granules of Convolvulus arecnsis, Lilium longiflorum, Crinum amabile, and Ranunculus acris, will convince any one of the correctness of this explanation; both of the nature of these lines, and of the reasons for their invuriable appearance in cach granule at the same moment.

In most clliptical pollen, covering cach of the fissurcs, an oval piece of membranc is to be observed, the usc of which I conceive to be to prevent the pollen tubes from escaping too

- Malpighi's comparison of granules of this form to grains of wheat is by no means innpl, but still without the above cxplanation it is inconaplete, inasmuch as it does not account for the constant appecurance of the furrow.

Alm. of Mrg. N. Hisl. Vol. viii. 
readily from the cxtinc, to which it docs not appear to be organically united, as on the application of water it is seen to curl up and fall off the granules. It is also met with in Centaurium, Sculymus, Dipsacus, Scabiosa, and some allicd gencra; in these instances it sometimes has an attachment to the extinc.

The extine, or protective membraue of the pollen grain, on rhich its shape depends, is of much greater substance than the intine, which is so fine, that rarely can any nppreciable thickness of it be detected. It is scldom, if cver, a simple hounogencous membranc, being most generally formed by the npposition of a number of ccllules held together by " organic inucus," which give to it a reticulated appearance, very obvious in many of the Liliacec, as well as in a great varicty of other plants. In most hispid pollen, where the same reticulated structure may be traced, from the centre of each cell of the networl, cither one of the numerous spines which cover this form of pollen grain may be scen to arise, or, where this is absent, an aperture for the passage of a pollen tube will be apparent.

If this vicw of the structure of the extine be correct, then must it consist of tro layers, as each cell forms a shut-sac.

By some obscryers the cxternal tunic of the pollen grain is said to present a granular structure. It often presents a gramular appearance, which is deceptive, and which I have found to arise from the circumstance of the particles in the fovilla being visible through their transparent coverings.

It has been matter of doubt whether the extinc be extensible or not; that it really is so in some cases to a considerable cxtent, is apparent from the following fact, the only one with which I ain acquainted which distinctly proves it. 'The surface of the pollen granule of Camna indica is covered with numcrous points, having their free cxtremities perforated. When the pollen is immersed in water the spines disappear, leaving sinall apertures on the surface of the now smooth cxtine; cach granule at the same time having enlarged to about thrice its original size. This change occurs with greater rapidity if a clilute mincral acid be used instead of watcr. All kinds of pollen appear somewhat lauger in water, but this depends upon the magnifying power of that liquill. The intine docs not cxpand in an cqual proportion with the extine; but being pressed upon equally on all sides by the water which is imbibed by the extine, is forced inwards, and a large space filled with fluid is left between the two nembranes.

After diligent and repeated search, I have at last succecded in making out the plano-convex bodics (Zwischenorpern) described by Fritzsche as bcing particularly visible in some $\mathrm{Mal}$ - 
vacea, in a species of Hibiscus, $I$. africamus. IIe represents them as existing in most hispid pollen, the apertures in which for the passnge of the pollen tubes they cluse, being placed between the extine and intine, with their convex surfaces resting upon the latter. If the pollen of the aborc-named species of Hibiscus be allowed to remain in water for a short time, the pollen tubes will be seen to have cmerged some clistance from the intine; and upon the cxtremitics of many of them those pieces of nembrane will be noticed, which are however more fiequently concaro-convex than plamo-convex. Although I have not scen these bodics closing the apertures in the extine, it may be inferred with tolerable certainty that they perform the oflice nseribed to them, from their position at the terminations of the pollen tubes. Those who inay wish to obscrve them will not experience the same difficulty that I have done, knowing the species and the manner in which to look for them. They are not present in the pollen of the Ipomece.

The surface of all pollen is covered with a thick tenacious matter, which, according to Mohl, is most abundant upon that which is hispid; but it is at lenst ns inuch so on the pollen of many species of Liliacee, which are not hispid, but reticulated. If this viscid substance is to be regarded ns a secretion, then must the extine be provided with glands, or some other peculiar organization for its formation; for a truc secretion can only result from organization of some kind or other, and, in the vegetable hingdom, may be defined to be a new product, eliminated from the sap through the instrumentality of glands or other structural media. My own opinion is, that it is a sccretion, if not formed by the external membranc of the pollen grain itself, derived from the cell in which it is originally developed. I was at first inclined to consider it as n merc exudation, consisting of the thinner parts of the fovilla; but its appearance and consistence differ so much from this, that I belicre the opinion to be scarcely tenible. 'This sccretion fulfills an inportant indication in preventing the too easy dispersion of the pollen granules, which it slightly holds together, and which would be scattercd far and near, widle of its destincd mark, by every breath of wind.

l'ollen granules, though usually scparate, are occasionally. found united. This union is cither tempornry, the mediun which retains them in contact with each other being either a tenacious secretion, or filaments of the cellular tissue derived from the breaking up of the cclls in which the granules are originally developed; or it is permancnt and organic. W'c II 2 
find the first mode of union in the pollen grains of the Epilobia*, Salpiglossis alropurpurea, and in Lechenaultia formosa, while the second is met with in all the genern of the natural order Ericuccec which I have had an opportunity of examining, in the Acacic, Mimose, Junci, many species of Orchidacece, and in Oxyanthus spcciosa. Some of thesc grains, though they usually are pernanently attachecl, are yet capable of scparntion; but others of them ngain, as the Ericacce, \&c., nere so intimately joined, that they never become separatcel. 'The number of pollen grains thus united together is definitc, being cither four, or multiples of four up to sixtecn, but the first number is of the most frequent occurrence; thus there are four in the Ericacece, Epilobia, Junci, Orchidacere, Oxyanthus speciosa, and Salpiylossis atropurpurea, Lechenaullia formosa and Mimosa mexicana. In Acacia rigens there are cight, disposed on the same plane; in Acacia decipiens twelre, six being disposed on the same plane, while three are placed in the centre, on either side of the flat figure so formed; and in Acacia linearis there are sixtccn, cight upon the same plane and four on either sidc. It is to be obscrved, thant dark lines run between every four grains, indicating either their original separation or their tendency to become so separated. When the union of pollen grains occurs in fours, they are citherdisposed upon the same plane, ns in the Epilobia and $L c$ chenuullia formosa, or they nppear as if one iris placed upon the other three, all the granules bearing preciscly the same relations to cach other, and whicherer one is uppermost, the rest being similarly circumstanced in reference to it. Onc exception occurs to the law of the union of pollen grains in fours in Epilobium roseum, where they generally unite in threcs.

As a rule, but one mode of arrangement prevails among the pollen grains of the same species.

Pollen grains are often held together by a thready substance, supposed to be derived from the rupture and breaking up of the cells in which they are primarily formed, in the meshes of which they become cither entingled, or to which they are attached by the secretion which covers their surface. It appears to me that neither the origin nor use of these thresds are rightly made out. They are found in great abundance in the pollen of the Ericacec; Fuchsia, Enothere, and other Onagrurice.

The size of the pollen granule differs as materially as docs its form and structurc, as will be obvious from a perusal of the following table of relative sizes, although in the same

- The granules in Epilobium anguslifolium are not united, resenbling much n:ore those of the Clarkias than the Ejpilobiums. 
Mr. Hassall on the Structure of the Pollen Granule. 101 species and in genera of the same fumily it is pretty uniform.

'The micrometer employed was a glass one, and dividch in the ratio of 249,000 spaces to the inch.

$$
\begin{aligned}
& \text { Cobma stipularis } \ldots \ldots \ldots \ldots \ldots\left\{\frac{5}{249,000}\right. \\
& \text { Lavatera accrifolin } \ldots \ldots \ldots \ldots \ldots\left\{\frac{4}{2+1,000}\right. \\
& \text { Gcranium sylinticum ......... }\left\{\frac{2 !}{2+9,000}\right. \\
& \text { Fuchsin fulgens } \ldots \ldots \ldots \ldots \ldots\left\{\frac{2}{2-4,(0) 0}\right.
\end{aligned}
$$

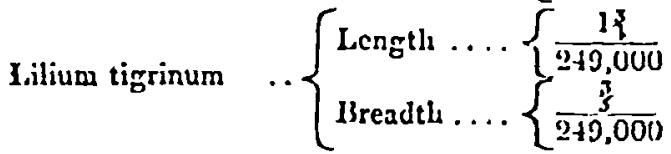

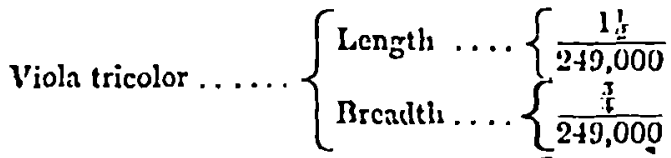

$$
\begin{aligned}
& \text { Salvia patens } \ldots \ldots \ldots \ldots \ldots \ldots\left\{\frac{1}{2+3,000}\right.
\end{aligned}
$$

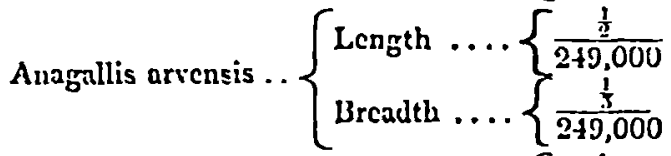

$$
\begin{aligned}
& \text { Baucra rubioides ............ }\left\{\frac{\frac{3}{1 \sqrt{1}}}{2+0,000}\right. \\
& \text { Myosotis palustris } \ldots \ldots \ldots \ldots \ldots\left\{\frac{\frac{3}{1 i}}{249,000}\right. \\
& \text { Mimosa marginata ........... }
\end{aligned}
$$

The colour of the pollen is extremely various and often brilliant. In Gilia achilleafolia and Pelunia violacea it is of a dark blue. In Collomia rosca it is of a bright cacrulcan bluc; decp red in Cleome spinosa; of a reddish brown or mahogany colour in Lilium tigrinum; and scarlet in IIuchera americana and Verbascum Thapsus. In P'upuver Rhacas and 'Tulipa Gesneriana nearly black. In Convolvulus sepium opakc white; and yellow, the most conmon colour of the pollen, in Lilium album and longiforum, owing to the clense yellowcoloured sccretion with which the granules are corered. $\mathrm{D}_{\mathrm{r}}$. Lindley says that the pollen occnsionally assumes every colour exeppt green; it is howerer perfectly green in Pentstemon 
pentaphyllum, Bessera clegans and Lythrum Salicaria ; in this last it is curious to notice, that while the pollen of the upper stamina is green, that of the lower ones is of a bright sellow.

Jollen tubes are prolongations of the intine, and are filled with the fovilla, which passes into them by gravitation. They vary much in number, size, and arrangement; they issuc cither through fissures or npertures in the extinc, and wherc there are three envelopes, through sinilar provisions in the second also. Execpt in some few instances, I have not becn able to discover any provision in the cxtine for the escape of the pollen tubes. 'I'hese exceptions occur in the genera Camua, Strclitzia, Roscoea and Hedychium, all of which belong to closely-allied orders, and in which the extine, which is of great thickness, forns a shut-sac. If water, and more quickly if dilute nitric acicl, be applied to the pollen, the granules are scen to enlarge a little, and the extine to crack irregularly, but often scparating into three unequal pieces; while the intine, having undergone no change except $₫$ slight increase of sizc, and still containing the fovilla, frequently disengages itself from its cnvclope and floats away from it. This cracking of the extine is assurcelly the natural mesns by which the pollen tubes are afforded an outlet; and it is not necessary that the intine should be denuded at any particular spot, for wherever it is so it possesses the power of elongation, or rather yrowth. In one or two cases the apertures are provided with valves, as in the different species of Passiffora, as first noticed by Purkinje. Fritzsche has described one valve in the grasses, two in the nettle, four in the ornnge, and six in the primrose. Although I have searched witl care for these valves, I have not been ablc to detect any trace of them, and am strongly inclined to deny their cxistence in any of these plants.

The primary form of the pollen of the orange precludes the possibility of its being furnished with regular valves, the pollen tubes issuing through fissures and not circular apertures; while had a valve been present in the grasses, I think I must have detected it in the pollen of the Zea Mfays, which is of n very large size, and in which the apertures for the cseape of the pollen tubes are very visible. The nettle I believe to possess three pollen tubes.

The emission of the pollen tubes is produced, artificially, by the action of the mineral acids and water, and naturally, partly by the rarefaction of the contents of cach pollen grianule by the sun's heat * (the rarefied fovilla distends the shell

- The effect of heat upon the pollen has occasionally been demonstrated when I have been examining it under a strung rellected light of the sun, by the conission of the pollen tubes, and cren ruplure of the intine. 
of the pollen grain, which produces pressure upon its contents, nud assists in forcing them out in the only direction in which they can issuc, namely, through the openings provided for the purpose), partls by the granules imbibing a portion of the stigmatic secretion, some of which gets between the outer and inner membranes, producing pressure upon the latter, and partly by the stimulating effect of that sccretion.

l'ollen tubes are supposed to be clongated by incans of the distension or stretching of the intine. This opinion alppears to une to be crroncously entertained. It is difficult to conceive any membrane to be endowed with such immense powers of expansion as would be required for it to afford a covering to the whole pollen tube, lengthened as it often is to such a great extent in its passage through the style. 'Thus in Crinum amabile the pollen tulue has to pass through a space 1875 times the diameter of the pollen grain before reaching the ovarium. In Cleome spinosa 2710 times. In Oxyanthus speciosa 4.4S9 times the dinneter of the pollen grain, and in Colchicum aulumnale 9000 times. Pollen tubes are frequently met with of considcrable length on parts of the flower distant froun the stigma, proving that the stigmatic fluid is not essential for thcir growth, slthough it doubtless favours it.

I an of opinion, therefore, that pollen tubes are growths and not mere clongations of the intine; and that as they grow a vacuum is formed within them, into which the fovilla passes. $\Lambda$ the same time, I do not mean to deny the fact of the intine being cxtensible; it is no doubt highly so, as proved by the great length of the pollen tubes emitted under the action of dilute nitric acid in some cases.

W'ere pollen tubes but mere extensions of the intine, it might with reuson be expected that the size of the granules and consequent extent of the intine would bear some relation to the distance which they have to travel through the stigmatic tissue before reaching the ovary, and that the greater the distanee the larger would be the pollen grains; but no such relation exists.

I am at present inclined to regard the active molecular bodics in the fovilla, which have attracted so much the intercst and attention of physiologists, as nothing more than particles of that fuid which have become scparated into little masses or globules. 'The fluid nature of these particles is proved by their great diversity of form and size, by their transparency, and by their trailing, or "tailing *," as they

- "I'ailing" is a term used by druggists to signify the clongation of furm which, the globules of impure quickrilver undergo in passing orer paper. 
pass along the surface of glass. Again, the internal mentbranc of the pollen grain of Strelitzia lumilis, when denuded of the cxtinc, prescuts a cellular appearance, which is orring to the prescuce of numerous globules of various sizes contained in the forillat, of which, in this instance, it appears to be cntircly composed, and which arc scen through its transparent cnvelope. I could not detect any other bodics but these globules, which I regarl as fluid for the reasons just given. The npplication of iodine to the forilla, contrary to expectition, produced no effect, and a solution of potash but little apparcut results.

1 look forward to another opportunity of making more cxtended observations upon the nature of these so-ealled moleculcs.

Being anxious to ascertain whether stimuli would produce any effect upon the pollen, various solutions were applied with a vicw to determine this point. The results following the various applications cmployed were as follows :-solutions of the mincral acids, whether sulphuric, nitric or hydrochloric, all occnsioned, with more or less degrec of force, the protrusion of the pollen tubes. 'Their modle of action is not very clcar; but it may be that they produce some astringent effect unon the outer coating of the pollen grain, so as to cause the principle of endosmosis to operate with greater power. Sometimes these acids, and more particularly the dilute sulphuric acid, rupture the inner membrane, and then the fovilla escapies from its interior; but most frequently the pollen tubes are cmitted, covered by the intine, which remains cntire, and it is to cxplain this protrusion of them that the above cxplanation is offered. The concentrated sulphuric acid almost always destroys the intine, and frequently also blackens and chars the cxtinc. A solution of the nitric acid, in the proportion of two of the strong acid to threc of watcr, is perhaps the best application for occnsioning the cmission of the pollen tubes; but it is as well to have solutions of all the acids of various strengths, for where one fails another will often produce the elesired cflect. 'The action of the hydrochloric acid is wcakcr than that of cither of the others. Solutions of ether and sal volutile produced a marked cffect. When cither of these were allowed to fall from a glass on the pollen, its granules became distinctly agitated and ınoved about with considerable velocity, sometimes for the space of tro or threc minutes. $\Lambda$ likic effect, but to a nuch less extent, resulted from the cmployment of tincture of cantharidles, tincture of capsicum, proof spirit, sulution of nitrate of silver in proof spirit, and essence of ginger, while liquor ammonize and po. 
tassa produced no result. It is to be remarked, that all those applications which occasioned any motion of the pollen contained in greater or less proportion of spirit in them, and that the most volatile liquitls, xther and sal volatile, gave rise to the most marked effect. 'This very obvious motion of the pollen granules is certainly not to be referred to any action of the irritants employed upon them, but to currents in the nuills. That this is the real explanation to be given of the phanomenon is satisfactorily proved by the two following facts: Ist. If a small quantity of cither xther or sal volatile be allowed to remain for a fer minutes in a watch-glass and the pollen be then added, no motion will follow, the more volatile portion of these liquids having craporated; and 2nd, the particles of flour will be cqually affected by the application of the before-mentioncd solutions. Water also will sometimes cause the emission of the pollen tubes, the principle of endosmosis being called into operation. This cmission of the pollen tubes is not the nct of an instant, but occupics an appreciable time, producing the impression on the mind of some continuous force operating in occasioning it, such as that of cndosmosis alrendy referrcd to.

The extreme care taken by nature to ensure the fertilization of the sced, a process so essential to the well-being and almost the existence of man, is very striking, and some of the beautiful provisions by which this important effect is so constantly brought about, it is my intention now to notice. First, then, the lining membrane of the anther, as pointed out by Mirbel in 1808, is composed of cellular tissue of a fibrous charactcr, which forms an innumerable quantity of little springs* which are lighly clastic, and when dry contract and pull open the valves of the anther, allowing the pollen to cscape. 'This clastic tissue is deprived of its fluid by means of the cndosmosis carricd on by each individual grain of pollen, nud this cxhaustion of its fluid is only completed at the period of the maturity of the pollen. Thus by this uncrsing contrivance, not alone is the precise period of the opcning of the anther, viz, at the perfection of the pollen, provided for and determined on, but it results from it also, that the pollen only should be exposed in the weather most suilable for the performance of its function, that is, in dry weather. The injurious cffect of a continuance of rain in destroying the fertilizing power of the pollen is well known, and is to be cxplaincd by the rupture of the granules from the grent quantity of water inbibed by endosmosis; and this consequence of

- This preuliar arrangenent of the fibres of the lining membrane of the anther is very plainly secn in the common nettle. 
wet would be attended with more serious results reere it not for another wise and effectual provision. The individual flowers composing a bunch, as well as the different bunches of a plant or shrub, come into blossom at successive intervals, the orrler of their expansion depending mainly, I belicse, upon the position of the flower, whether it be in a more direct line or not for the accession of sap, on the size of the peduncle, as well ns on the order of the derelopment of the flower buds themselves*: thus, if the pollen at one period be destrojed, it is soon replaced by the unfolding of more blossoms and bursting of anthers : this constitutes the sccond means by which the efficiency of the pollen is ensured. W'e find a third in the position of the stamens in reference to the pistil, which they often surround, embrace, or overhang, so as to render the appplication of the pollen to the stigmatic surface a matter of ccrtainty.

Again the filaments of some anthers are furnished with elastic joints, which at a certain period, that is, when the pollen and stigma are in a fit condition, contract and start towards the pistil with a jerk, dispersing the contents of the anthers around them by the suddenness nnd violence of the motion. I may perhaps under this head refer to two instances of irritability, which I have nerer secn mentioned in beoks, and which are ccrtianly not gcnerally known. 'The first occurs in Cormus canadensis: the corolla of ench flower, a number of which are contained in a common involucrum, cousists of four segments; these for somic time are folded over the other flornl organs and meet in a common central point, where they coliere by means of some secretion. Towarls their tips, on what is the upper surface, while thus closed, arises a long spine or hair. 'The staminn are also four in number, and arise from the top of the calyx in the intervals between the petals, and at about half their length are bent inwards towards the pistil at a very acute angle, being retaincd in this position by the corolla which infolds them. "The base of cach petal, as well as the angle of inflection of each filament, are furnished with an clastic joint, so that if one of the spines be slirithy touched, not only docs each segment of the corolla fly back, but the stamina, the restraint being removed from off them, start up, scattering the pollen of the anthers around them, some of which, it is beautiful to obscrve, in viewing this plinenomenon under a low power of the microscope, invariably alights upon the stigma, and is there retained by means of the secretion with which it is furnished.

* The cause of the irregular ripening of many kinds of fruils and sceds aduits of a similar cxplanation. 
If the joint of the filament be touched where it protrudes between the petnls, no such effect as I have described will be produced, but the moment the hair is touched it takes place; now the presence of these hairs affords is very interesting instance of design. They are connected with the joint of each petal by means of a raised line of elastic tissuc which runs along their centre, and which doubtless scrves to convey the impression or shock, imparted to the hairs most frequently by incans of insects, to the joint, causing it to contract; the dispersion of the pollen and conseruent fecundation of the uvule being therely renderes more certain.

The second instance to which I shall refer is witnessed in the common stinging nettle, Urtica dioica : the number of stamina in this plant is likewise four; these arc inclosed in a chalice or cup composed of four sepals, and the filanents are coiled inwirds; on the reflection of these sepals, or on the occurrence of any shock, the filaments disengaige themselecs, and not merely straighten, but turn as much outwards ns thcy were previously coiled inwards, the pollen being scattered, as in the former case, around them. If the filament of ench stamen be examined with the microscope, one surface of it, that is, the one which formed the concavity before its disengagement, but after, the convexity, is observed to be ringed, in the same way as the elastic spring of the sporangia of Ferns. An nnalogous instance of irritability occurs in Parielaria, an nllied genus*.

The stigmata of some plants, as for crample of Pavella Caffir, the Cumpanula \&c., cxtend so much beyond and above the anthers, that it is difficult to conceive in what way the pollen can reach them; but obscrvation affords an cxplanation of the means : at the time of the bursting of the anthers the stigma is on a level with them, and, appourently stimulated by contact with the pollen grains, subsequently rises up, carrying with it in its progress a quantity of the pollen.

Morcover, the application of the pollen to the stigma is rendered more certain by a cause, which, when not rightly considered, may appear trilling, but which, in its results, is far from being so. I nllude to the agency of insects, and of these, especially to the Aphides, and our benefactor the $3 \mathrm{ce}$, that busy labourer for man, who in rifing a flower of part of its sweets, $y$ ct in doing so confers upon it the means of its perpetuity by dispersing the pollen around, some of which nerer fails to reach the stigma. 'To many insects the pollen doubt-

- I now know that this second exninple of vegctable irritability or elasticity of tissue is nlluded to in Lindley's 'Natural Arrangement,' and also in Ileuslow's ' Descriptive and Plyssiolugical Butany:' 
less forns an important article of food, as does nlso the honcyed sccretion found in so many lowers, and arc both the inducements which bring them so many visitants. The chief use of honey in the occonomy of. a plant I conccive to be to allure insects for the purpose referred to.

'llhe last provision to which I shall advert, consists in the nmazing number of pollen granules produced by most flowers. In a single blossom of Leontodon Turaxacum I counted no less than 243,600 pollen granules. $\Lambda$ flower of l'xony furnishes on an avcrage 174 stamina, each containing 21,000 granules; these multiplied together give a total of $3,65.1,000$; and in an entire Rhododendron plant the pollen grains amount.ed to the wonderful number of $72,620,000$. This last result was arrired at by computing the number of anthers in each flower, with the contents of one, and the number of flowers nnd bunches. Great as these amounts are, they sink into comparative insignificance when contrasted with the myriads produced by a single forest trec. $\Lambda$ bulrush gave $144 \mathrm{grs}$. by weight of pollen. Inmense as the quantity of pollen is, provided for the fertilization of each flower, it is yet all necessary, so much bcing destroyed by various instrumentalities, to chsure the ccrtainty of a process, the failure of which would be attended with such calamitous results. Nature is scldom uselessly prodigal of her resources.

It is interesting to observe the relation which fiequently exists between the quantity of pollen and the more or less direct means of its application to the stigma ; this relation, however, is modified by the number of ova to be fertilized. Upon this sulject I hope shortly to make some detailed observations.

Various particulars referred to in the foregoing pages will be exhibited in the figures which are to accompany the second portion of this communication.

[To be continued.]

XIV.--Indian Cyprinida. By JoHx M'CuEnLdNd, Assistant Surgeon Bengal Medical Service.

[Continucd froin p. 16.]

24. 'T'ne $O_{p}$ sarions are $C_{y j p r i n i d e}$ that live upon other' spccies of thcir own class; they are no less remarkable for the peculiarity of their colours than for their remarkable structure and habits. Instend of the longitudinal stripes of the l'erilamps, they are characterized by transverse bands or spots, laving a tendency to form cross bars on the sidcs. 'The annlogy between the structure and clinracter of the Opsarions 